\title{
Editorial
}

\section{Apoptosis in reproductive biology}

\author{
Massimo De Felici \\ Department of Public Health and Cell Biology, University of Rome 'Tor Vergata', Rome, Italy
}

Recent studies aimed at a greater understanding of the occurrence and regulation of cell death in reproductive biology provide a promising new direction for novel approaches to understanding normal and pathological aspects of reproduction. Several instances of physiologically occurring cell death (programmed cell death, PCD), associated with reproduction and described 40 or 100 years ago (i.e. germ cell degeneration, follicle atresia and luteolysis, embryo implantation, homoeostatic maintenance and cyclicity of non-gonadal reproductive tissues), are now being re-examined by novel morphological, biochemical and molecular biology methods. The majority of these processes appear to display the features of apoptosis and some of them have turned out to be useful models to investigate the molecular mechanisms of this phenomenon. Two of the most interesting models deal with cell death in the ovary and testis and are separately reviewed in this issue of Cell Death and Differentiation (Tilly and Tilly, 1997; Dunkel and Erkkilä, 1997).

The earliest description of PCD within the ovary was made in 1885 during a detailed morphological analysis of rabbit follicle atresia (Flemming, 1885). Only recently, however, using sensitive biochemical assays to detect apoptotic markers (that is, formation of DNA ladders), has it been clearly established that the induction of apoptosis in granulosa cells is the trigger for atresia in a variety of animal species (Tilly et al, 1991; Hughes and Gorospe, 1991). In addition, it is now recognized that gonadotropins are the primary endocrine factors responsible for inhibiting apoptosis and atresia in developing mammalian follicles (Tilly et al, 1992, 1995). On the basis mainly of results of in vitro cultue of isolated rat or mouse follicles, the ability of FSH and LH to suppress apoptosis and atresia have been shown to interact with signals activated by intrafollicular growth factors. Moreover, gonadotropin-independent pathways probably contribute to the maintenance of granulosa cell survival whereas activation of Fas receptor plays a role in the negative selection of developing follicles. References on these arguments and a model of the hormonal mechanisms and cell-to-cell interactions required to maintain survival or to induce apoptosis in granulosa cells can be found in the Educational Corner of this issue (De Felici, 1997). It is important to note that apoptosis is involved in two other instances of cell death in the ovary: the massive degeneration of oogonia and oocytes during the fetal period (up to $90 \%$ of the female gametes are lost during this period) (Pesce et al, 1993; Coucouvanis et al, 1993) and the regression of the corpus luteum (Orlicky et al, 1992). It is now known that several pro- and antiapoptosis genes, including p53, c-myc and members of the $b c l-2$ and $l c e$ gene families, are expressed in germ cells or in somatic cells of the ovary. Current perspectives on the intriguing relationship between the regulation of apoptosis by hormonal and growth factors and death gene expression are extensively discussed in the review by Tilly and Tilly.

Spontaneous death of certain classes of germ cells has been shown to be a constant feature of normal spermatogenesis in many mammalian species (for a review, see Roosen-Runge, 1962). Morphological and quantitative studies indicate that germ cell demise is most commonly found in differentiating spermatogonia throughout testis development and that only $25 \%$ of the theoretically possible number of preleptotene spermatocytes is produced from the original population of spermatogonia (Huckins, 1978). Recent biochemical evidence links testicular cell death to increased internucleosomal apoptotic DNA fragmentation and shows that under pathological or experimental conditions, besides spermatogonia, spermatocytes and spermatides can also undergo apoptosis (Tapanienen et al, 1993; Shikone et al, 1994; Billing et al, 1995; Sinha Hikim et al, 1995; Callard et al, 1995). At least three cell death genes are expressed in the testes: bcl-2, bax and p53 (for references see the review of Dunkel and Erkkilä in this issue); However, the exact role of these genes has not been established. Interestingly, Fas ligand is expressed in Sertoli cells (Bellgrau, 1995), but whether it has a role in germ cell apoptosis is unknown. In their review, Dunkel and Erkkilä point out that three main factors play a role in determining the onset of apoptosis of the male germ cells: (1) the developmental stage of the animal; (2) serum levels of gonadotropins as well as intratesticular androgens induced by $\mathrm{LH}$; and (3) the stages of the seminiferous epithelial cycle. It should also be considered that, as in the ovary, gonadotropin-independent pathways probably contribute to the control of spermatogenic cell survival. For example, the c-Kit ligand expressed by Sertoli cells appears to be able to favour the survival of spermatogonia and spermatocytes (Packer et al, 1995).

On the wave of the renewed studies in cell death, apoptosis in reproduction is attracting interest in several broad fields of clinical investigation. Data reported in the present review by Dunkel and Erkkilä showing that cryptochidism-induced testis degeneration is associated with increased germ cell apoptosis and that hGC treatment dramatically increases this pehnomenon, demonstrate that apoptosis can be the mechanism of degenerative pathologies in reproduction. It is likely that characterization of the molecular basis of this process will provide new clues to explain some causes of infertility, to understand the pathological effects of chemotherapeutic compounds or 
environmental toxic agents on reproduction and the genetic defects that predispose people to reproductive abnormalities.

\section{References}

Bellgrau D, Gold D, Selawry H, Moore J, Franzusoff A and Duke R (1995) A role of CD95 ligand in preventing graft rejection. Nature 377: 630-632

Billing H, Furuta I, Rivier C, Tapanaine J, Parvinen Mand Hsueh JW (1995) Apoptosis in testis germ cells: developmental changes in gonadotropin dependence and localization to selective tubule stages. Endocrinology 136: 5-12

Callard GV, Jorgensen JC and Redding JM (1995) Biochemical analysis of programmed cell death during premeiotic stages of spermatogenesis in vivo and in vitro. Dev. Gen. 16: 140-147

Coucouvanis EC, Sherwood SW, Carswell-Crumpton C, Spack EG and Jones PP (1993) Evidence that the prenatal cell death in the mouse is apoptosis. Exp. Cell. Res. 209: 238-245

De Felici M (1997) Ovarian follicular atresia: a model for apoptosis. Cell Death Differ. 4: $260-261$

Dunkel L and Erkkilä (1997) Clinical aspects of male germ cell apoptosis during testis development and spermatogenesis. Cell Death Differ. 4: 171-179

Flemming W (1885) Uber dir bidung von richtungsfiguren in saugethieren beim untregang Gaafsher follikel. Arch. Anat. EntwGesch, pp. 221-244

Huckins C (1978) The morphology and kinetics of spermatogonial degeneration in normal adult rat: an analysis using a simplified classification of the germinal epithelium. Anat. Rec 190: 905-926

Hughes FM and Gorospe WC (1991) Biochemical identification of apoptosis (programmed cell death) in granulosa cells: evidence for a potential mechanism underlying follicular atresia. Endocrinology 129: 2415-2422

Orlicky DJ, Fisher L, Dunscomb N and Miller GJ (1992) Immunohistochemical localization of PGF2Á receptor in the rat ovary. Prostaglandins, Leukotrienes, Essential Fatty Acid 46: 223-229
Packer Al, BesmerP and Bachvarova RF (1995) Kit ligand mediates survival of type A spermatogonia and dividing spermatocytes in postnatal mouse testes. Mol. Repr. Dev. 42: 303-310

Pesce M, Farrace MG, Piacentini M, Dolci S and De Felici M (1993) Stem cell factor and leukemia inhibitory factor promote primordial germ cell survival by suppressing programmed cell death (apoptosis). Development 118: 1089-1094

Roosen-Runge EC (1962) The process of spermatogenesis in mammals. Biol. Rev. 37: $343-377$

Shikone T, Billig H and Hsueh AJW (1994) Experimentally induced cryptorchidism increases apoptosis in rat testis. Biol. Repr. 51: 865-872

Sinka Hikim APS, Wang C, Leung A and Swerdloff S (1995) Involvement of apoptosis in the induction of germ cell degeneration in adult rats after gonadotropinreleasing hormone antagonist treatment. Endocrinology 136: 2770-2775

Tapanienen Js, Tilly JL, Vihko KK and Hsueh AJW (1993) Hormonal control of apoptotic cell death in the testis: gonadotropin and androgens as testicular cell survival factors. Mol. Endrocrinology 17: 643-650

Tilly JL, Kowalski KI, Johnson AL and Hsueh AJW (1991) Involvement of apoptosis in ovarian follicular atresia and postovulatory regression. Endocrinology 129: 2799-2801

Tilly JL, Billing H, Kowalski KI and Hsueh AJW (1992) Epidermal growth factor and basic fibroblast growth factor suppress the spontaneous onset of apoptosis in cultured rat ovarian granulosa cells and follicles by a tyrosine kinase-dependent mechanism. Mol. Endocrinology 6: 1942-1950

Tilly JL and Tilly KI (1997) The genes of cell death and cellular susceptibility to apoptosis in the ovary: a hypothesis. Cell Death Differ. 4: 180-187

Tilly JL, Tilly KI, Kenton ML and Johnson AL (1995) Expression of members of the bc2 gene family in the immature rat ovary: equine chorionic gonadotropin-mediated inhibition of apoptosis is associated with decreased bax and constitutive bcl-2 and bcl- $x_{\text {long }}$ messenger ribonucleic acid levels. Endocrinology 135: $1845-$ 1853 